\title{
AlpArray-Italy: Site description and noise characterization
}

\author{
Aladino Govoni ${ }^{1}$, Luciana Bonatto ${ }^{1}$, Marco Capello ${ }^{3}$, Adriano Cavaliere ${ }^{4}$, Claudio Chiarabba ${ }^{1}$, Ezio D'Alema ${ }^{2}$, \\ Stefania Danesi ${ }^{4}$, Sara Lovati ${ }^{2}$, Lucia Margheriti ${ }^{1}$, Marco Massa ${ }^{2}$, Salvatore Mazza ${ }^{1}$, Francesco Mazzarini ${ }^{3}$, \\ Stephen Monna ${ }^{1}$, Milena Moretti ${ }^{1}$, Anna Nardi ${ }^{1}$, Davide Piccinini ${ }^{3}$, Claudia Piromallo ${ }^{1}$, Silvia Pondrelli $^{4}$, \\ Simone Salimbeni ${ }^{4}$, Enrico Serpelloni ${ }^{4}$, Stefano Solarino ${ }^{1}$, Massimiliano Vallocchia ${ }^{1}$, Marco Santulin ${ }^{2}$, and the \\ AlpArray Working Group* \\ ${ }^{1}$ Istituto Nazionale di Geofisica e Vulcanolgia, Via di Vigna Murata, 605, Rome, Italy \\ ${ }^{2}$ Istituto Nazionale di Geofisica e Vulcanologia, Via Bassini 15, 20133, Milano, Italy \\ ${ }^{3}$ Istituto Nazionale di Geofisica e Vulcanologia, Via della Faggiola, 32, 56126, Pisa, Italy \\ ${ }^{4}$ Istituto Nazionale di Geofisica e Vulcanologia, Via Donato Creti, 12, 40128, Bologna, Italy \\ *A full list of authors and their affiliations appears at the end of the paper.
}

Correspondence to: Aladino Govoni (aladino.govoni@ingv.it)

Received: 30 September 2016 - Revised: 16 January 2017 - Accepted: 8 February 2017 - Published: 13 March 2017

\begin{abstract}
Within the framework of the European collaborative research initiative AlpArray (http://www.alparray.ethz. ch), the Istituto Nazionale di Geofisica e Vulcanolgia (INGV) deployed overall 20 broad-band seismic stations in Northern Italy and on two islands in the Tyrrhenian Sea (Capraia and Montecristo) during Fall-Winter 2015.

The temporary deployment (16 stations) will run for two to three years and 4 INGV National Seismic Network accelerometric sites are now equipped with additional permanent broad-band sensors. The 16 temporary stations are equipped with REF TEK 130 digitizers and Nanometrics Trillium Compact $120 \mathrm{~s}$ sensors, a couple have Nanometrics Trillium 120P sensors and one a Streckeisen STS2.

For each site we describe the settings and discuss the noise levels, the site effects and the preliminary sensitivity analysis.
\end{abstract}

\section{Introduction}

We describe here the deployment, managed by Istituto Nazionale di Geofisica e Vulcanolgia (INGV), of 20 new real-time broad-band seismic stations in Northern-Central Italy. The deployment contributes to the AlpArray Seismic Network (AASN) in the framework of the AlpArray project (www.alparray.ethz.ch), a large European collaborative research initiative (AlpArray Seismic Network, 2015). The aim of AlpArray is carrying out cutting edge research to advance our understanding of the deep structure, geodynamics, tectonics and seismic hazard of the greater Alpine area (AlpsApennines-Carpathians-Dinarides orogenic system) and integrating seismological data and other geophysical observables with geological studies.

The project relies on a high-end seismological array complementing the permanent stations coverage by national networks. The characteristics of the array were designed to maximize the resolution of geophysical imaging in order to progress our knowledge on the 3-D structure and physical properties of the lithosphere and of the upper mantle. The success of such a project, based on the deployment of heterogeneous type of instrumentation, relies on the collection of high quality data. For this reason, each AASN station has to fulfill quality standards (specified in the AA technical strategy document, www.alparray.ethz.ch/ organisation/documents) concerning site selection, installation techniques, data management and noise performances. More than 50 research institutes and seismological observatories from 18 countries are involved in the AlpArray scientific project, while 24 institutions are contributing to the AASN with high quality data from $390+$ permanent and $260+$ temporary broad-band seismic stations installed in 10 countries in the great Alpine area, to build up a unique data set of at least two years (officially starting on 1 January 2016).

To achieve an average spacing of $\sim 40 \mathrm{~km}$ between each broad-band site, the initial AASN plan has identified, within the Italian border, 32 temporary sites to complement the 
Table 1. The INGV Z3 network deployment status in Italy (July 2016). 4 of temporary planned sites were close to accelerometric sites and are now part of the National Seismic Network IV. Four sub-teams (PI, BO, MI, CNT) are responsible for the different geographical sectors: Tuscany and islands (PI), Emilia-Romagna and SE Veneto (BO), Lombardia and neighboring sites (MI), Veneto and Friuli Venezia-Giulia (CNT). Last column specifies the soil type: SOFT (a - alluvial, s - sand); ROCK (s - sedimentary, v - volcanic).

\begin{tabular}{|c|c|c|c|c|c|c|c|}
\hline code & Place & Installation & by & RT & \multicolumn{2}{|c|}{ Instrument } & note \\
\hline Z3.A300A & Muzzana Del Turgnano & $2015 / 10 / 28$ & CNT & Y & REFTEK-130S & TRILLIUM-120C & SOFT(a), Building \\
\hline Z3.A301A & Isiata & $2015 / 10 / 29$ & CNT & $\mathrm{Y}$ & REFTEK-130S & TRILLIUM-120C & SOFT(a), Urban Free Field \\
\hline Z3.A302A & Resana & $2015 / 10 / 30$ & CNT & $\mathrm{Y}$ & REFTEK-130S & TRILLIUM-120C & SOFT(a), Building \\
\hline Z3.A303A & Lido Pellestrina & $2015 / 10 / 26$ & CNT & $\mathrm{Y}$ & REFTEK-130S & STS-2 & SOFT(s), Building \\
\hline Z3.A304A & Adria & $2016 / 02 / 05$ & $\mathrm{BO}$ & Y & REFTEK-130S & TRILLIUM-120C & SOFT(a), Building \\
\hline Z3.A305A & Porto Tolle & $2015 / 10 / 29$ & $\mathrm{BO}$ & $\mathrm{Y}$ & REFTEK-130 & TRILLIUM-120C & SOFT(a), Building \\
\hline Z3.A306A & Viano & $2015 / 11 / 04$ & $\mathrm{BO}$ & $\mathrm{Y}$ & REFTEK-130S & TRILLIUM-120C & ROCK(s), Building \\
\hline Z3.A307A & Oasi Bentivoglio & $2015 / 11 / 05$ & $\mathrm{BO}$ & $\mathrm{Y}$ & REFTEK-130S & TRILLIUM-120C & SOFT(a), Building \\
\hline Z3.A308A & Longastrino & $2015 / 11 / 03$ & $\mathrm{BO}$ & $\mathrm{Y}$ & REFTEK-130S & TRILLIUM-120C & SOFT(a), Building \\
\hline Z3.A309A & Cesena & $2015 / 10 / 28$ & BO & $\mathrm{Y}$ & REFTEK-130S & TRILLIUM-120C & SOFT(a), Building \\
\hline IV.SARZ & Sarezzano & $2015 / 12 / 11$ & MI & $\mathrm{Y}$ & GAIA2 & TRILLIUM-40 & permanent, Building \\
\hline IV.ORZI & Orzinuovi & $2015 / 11 / 24$ & MI & $\mathrm{Y}$ & REFTEK-130 & TRILLIUM-40 & permanent, Building \\
\hline Z3.A312A & Bozzolo & $2015 / 12 / 30$ & MI & $\mathrm{Y}$ & REFTEK-130 & TRILLIUM-120P & SOFT(a), Building \\
\hline Z3.A313A & Volta Mantovana & $2015 / 12 / 30$ & MI & $\mathrm{Y}$ & REFTEK-130S & TRILLIUM-120P & SOFT(a), Building \\
\hline IV.OPPE & Oppeano & $2015 / 11 / 11$ & MI & $\mathrm{Y}$ & GAIA2 & TRLLIUM-40 & permanent, Building \\
\hline IV.ZONE & Zone & $2015 / 12 / 01$ & MI & $\mathrm{Y}$ & GAIA2 & TRLLIUM-40 & permanent, Building \\
\hline Z3.A316A & Montecristo & $2015 / 11 / 03$ & PI & $\mathrm{N}$ & REFTEK-130 & TRILLIUM-120C & ROCK(v), Building \\
\hline Z3.A317A & Capraia & $2015 / 12 / 15$ & PI & $\mathrm{Y}$ & REFTEK-130 & TRILLIUM-120C & ROCK(v), Building \\
\hline Z3.A318A & Donoratico & $2015 / 11 / 16$ & PI & $\mathrm{Y}$ & REFTEK-130S & TRILLIUM-120C & ROCK(s), Free Field \\
\hline Z3.A319A & Santa Luce & $2015 / 11 / 12$ & PI & $\mathrm{Y}$ & REFTEK-130S & TRILLIUM-120C & ROCK(s), Free Field \\
\hline
\end{tabular}

permanent stations geometry. Due to the absence of national calls for this type of fundamental research projects the AlpArray-INGV deployment has been funded with internal resources up to a maximum of 20 sites. The INGV mobile seismic stations pool, the "Rete Sismica Mobile" (ReMo, Moretti et al., 2016) of the Centro Nazionale Terremoti (CNT), has provided most of the instrumentation. The other 12 temporary sites in Italy have been installed and are managed by Institute of Geophysics and Swiss Seismological Service, ETH Zürich (Molinari et al., 2016).

\section{The temporary network layout and requirements}

All AASN sites have a naming code Z3.AxxxA where Z3 is the FDSN network code, the first A is reserved, $\mathrm{xxx}$ is a three digit code range assigned to each country and the last A can be turned to $\mathrm{B}, \mathrm{C}, \ldots$, etc. in case of major $(>10 \mathrm{~m})$ site changes.

The complete network plan is shown in detail in Fig. 1. The numeric range assigned to Italy is 280-329. The 12 sites managed by ETH have a numeric code in the range 280-299 and are located mainly in the NW part of Italy. The 20 sites managed by INGV have a numeric code ranging from 300 to 329 and are located in the NE area, the Po plain area and Tuscany (see Table 1). All permanent broad-band stations located in Northern and Central Italy $(\sim 150)$ are contributing to the AASN and are managed by several italian Institutions (see Table 2 for a complete list).

Scouting, installation and maintenance of INGV AlpArray stations were performed by four sub-teams, each of them responsible for one geographical sector (see Table 1).

Eventually, after a revision of the original installation plan and after a cost-benefit evaluation, we decided to turn 4 out of the 20 sites selected for temporary deployment into permanent installations of the Italian National Seismic Network. These sites have been registered with the IV network code.

\subsection{Site selection}

As a rule permanent broad-band sites are carefully selected in extremely low noise remote areas and the sensor vault is usually designed and built to minimize all sources of signal pollution like thermal and atmospheric variations. Such a careful scouting is not applicable to temporary seismic projects for which site selection, permissions and installations have to be accomplished in a short time (typically 2-3 months) and with limited resources. Moreover the AASN site must respect also a geometrical constraint: installation must be performed within $3 \mathrm{~km}$ from the theoretical location $(6 \mathrm{~km}$ can be acceptable in very difficult situations).

In our temporary deployment we looked for a satisfactory compromise between site accessibility, safety, low seismic noise level, power supply availability and possibly also good 


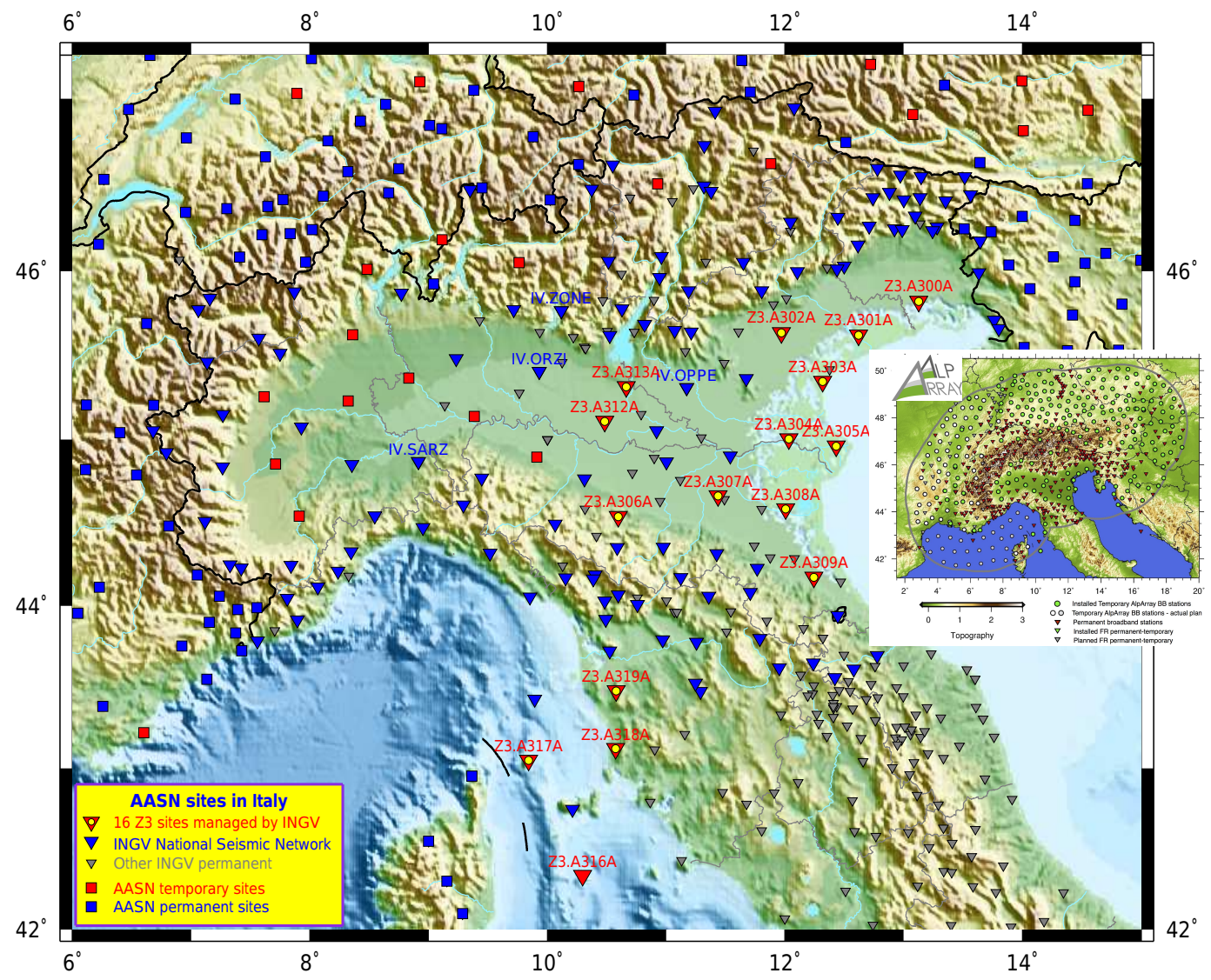

Figure 1. The AlpArray Seismic Network in Italy: the red inverted triangles are the temporary broad-band sites installed and managed by INGV, real-time stations have a yellow dot (all but Z3.A316A) The blue inverted triangles are the permanent Italian sites that belong to the AASN (in gray the other non broad-band permanent sites). The red and the blue squares are respectively the temporary and the permanent sites of the AASN outside Italy. The complete plan of the AASN is in the inset (from the project site).

Table 2. Permanent broad-band stations in Italy contributing to the AASN: 115 sites.

\begin{tabular}{llll}
\hline Code & Sites & Name & Manager \\
\hline IV & 48 & Italian National Seismic Network & Istituto Nazionale di Geofisica e Vulcanologia (INGV) \\
GU & 28 & Regional Seismic Network of North Western Italy (RSNI) & University of Genova (UniGE) \\
OX & 20 & North-East Italy Seismic Network (NEI) & Istituto Nazionale di Oceanografia e di Geofisica \\
& & & Sperimentale (INOGS) \\
MN & 4 & MedNet Project (MedNet) & INGV \\
SI & 7 & Province Südtirol & Zentralanstalt für Meteorologie und Geodynamik \\
& & & (ZAMG) \\
ST & 2 & Trentino Seismic Network & Geological Survey-Provincia Autonoma di Trento \\
\hline
\end{tabular}

mobile connection. The AASN requires that the noise levels should be $20 \mathrm{~dB}$ lower than the New High Noise Model (NHNM) (Peterson, 1993) on all components in the $1-20 \mathrm{~Hz}$ frequency range, 20 and $10 \mathrm{~dB}$ lower than the NHNM respectively for the vertical components and the horizontal components in the 30-200 s period range. These constrains apply to rock site and for soft soil are relaxed by $10 \mathrm{~dB}$. Meeting these requirements has proved to be quite difficult since most of the sites assigned to INGV are on large alluvial plains af- fected by a high cultural noise produced by population and industrial activities (i.e. Marzorati and Bindi, 2006). In these areas fulfilling both constraints (geometrical and low noise) has been extremely hard.

Whenever possible we preferred the basement of one storey buildings due to safety and accessibility In these cases we usually benefit also of power from grid and good UMTS coverage for data transmission. 

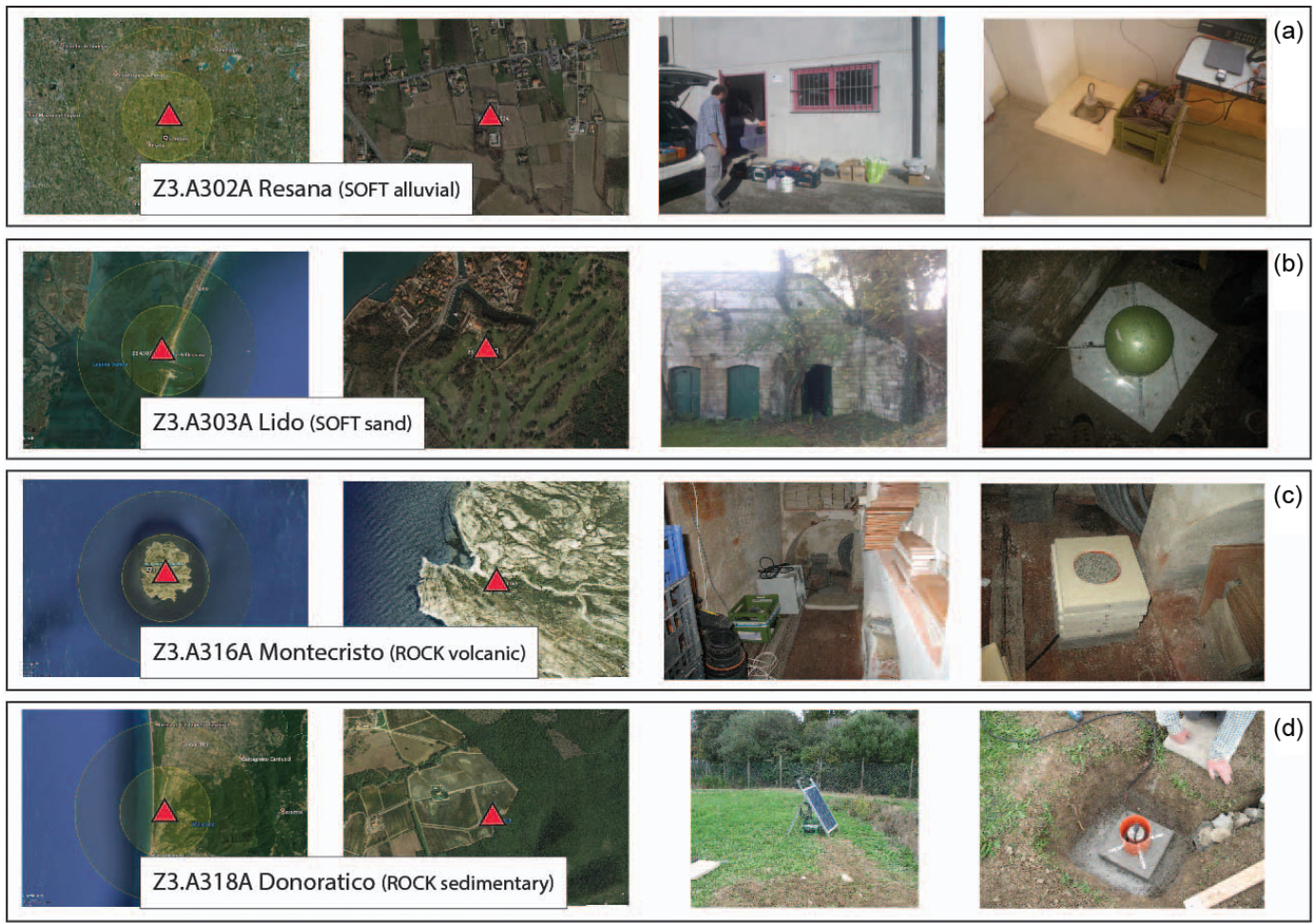

Figure 2. Examples of installations for four representative soil types (rows). The station position (red triangles) is indicated on distant (first column) and closer (second column) views extracted from Google Earth. Pictures from each installation are shown in the third and fourth columns. The stations are: (a) Z3.A302A, Resana (Treviso, Veneto); (b) Z3.A303A, Lido di Venezia (Veneto); (c) Z3.A316A, Montecristo Island (Livorno, Tuscany); (d) Z3.A318A, Donoratico (Livorno, Tuscany).

\subsection{Station design}

The INGV mobile pool seismic station is based on the REF TEK 130 digitizer (either model $\mathrm{S}$ or 01 ) storing data on standard 4 GB/8 GB Compact Flash disks. The station is supplied in a carrying box together with a standard $42 \mathrm{Ah}$ battery, GPS antenna, solar regulator, $80 \mathrm{~W}$ solar panel and all needed cables ready for deployment. Several types of broad-band sensors are available, mainly Nanometrics Trillium Compact $120 \mathrm{~s}$, Trillium 120P and a few Streckeisen STS2. All the stations installed have been Huddle tested with a $48 \mathrm{~h}$ long data acquisition against a reference station composed by a REFTEK 130S and a Streckeisen STS2 sensor, now installed on Z3.A303A (Lido, see Fig. 2a). Given a certain heterogeneity of the instrumentation (see Table 1) with two types of datalogger (REFTEK 130-01 and 130S) and 3 types of seismic sensors (1 Streckeisen STS2, 2 Nanometrics Trillium 120P, 13 Nanometrics Trillium Compact 120 s) the Huddle test can guarantee the accuracy of the sensor response data and the uniformity of the acquisition parameters. Moreover we have been able to exclude from the experiment some of the sensors in the pool that were showing deviations from the theoretical response.

The key factor in reducing the sensor noise at long periods consist in minimizing the thermal variations around the sensor A careful thermal insulation of the sensor is usually enough to meet the noise specifications (see installation photos in Fig. 2a and b). Wherever possible we used a standard double wall heavy plastic box reinforced with a supplementary $40 \mathrm{~mm}$ thick layer of polystyrene.

In the case of the Nanometrics Trillium Compact this is not always enough to ensure a low long-period noise level. The sensor is small and lightweight and these features might contribute to signal pollution due to the strain of the cable and to the high thermal capacity of the aluminium case. To minimize these effects the sensor is wrapped using a standard packaging film so that the sensor cable is kept firmly to the body of the sensor and reaches the ground with a glazing angle. This minimizes eventual stresses on the sensor from the cable but also the thermal contact of the aluminum case with the environment. A custom polystyrene box has been designed to insulate the sensor leaving the minimum air around the case. Using standard commercially available $40 \mathrm{~mm}$ polystyrene slabs, a number of $300 \times 300 \mathrm{~mm}$ tiles are easily cut. A $128 \mathrm{~mm}$ hole is drilled in the center of each tile that is put on top of the others aligned along the hole. The two uppermost tiles are not drilled at all. They just cover the assembly and guarantee that the thinnest part of the shield is at least $80 \mathrm{~mm}$ tick. The initial assembly of this box is visible in 
Fig. 3a. This work is basically easy enough to be performed also on site with the standard installation equipment.

To test the effectiveness of this solution we have acquired the data from both an insulated Trillium Compact and the reference STS2. Both sensors were placed nearby on the plinth in the laboratory and acquired with two different REFTEK $130 \mathrm{~S}$ units configured for the final field deployment. Without the thermal insulation the Trillium Compact appear to have a higher noise level respect to the bare STS2. With the insulation box the Trillium Compact has a noise comparable to the STS2 except for the vertical component that shows a bimodal behavior. PPSD plots computed using $48 \mathrm{~h}$ of continuous recording at 100 sps with the ObsPy library (Beyreuther et al., 2010; Krischer et al., 2015) are shown in Fig. 3b.

A comparative plot of the mean value of the PPSD is shown in Fig. 3c for each component with the New Low/High Noise model, the yellow band is the $-20 \mathrm{~dB}$ from NHNM zone required as maximum noise level for AASN stations on stiff soil. Both the Trillium horizontal components appear now to have lower noise than the STS2 above $20 \mathrm{~s}$ (indeed the Trillium EAST component does appear almost a shifted copy of the STS2, this may be due to the asymmetry of the plinth that is rectangular). The Trillium vertical component is bimodal and has an average noise level much higher the STS2 one for periods longer than $10 \mathrm{~s}$. Only a fraction of PPSD mimic the behaviour of the STS2 vertical component. This is likely due to the very low weight of the sensor and can be minimized burying the sensor with fine sand. This very low cost and easy to manufacture thermal shield has been used in several sites with satisfactory results. An example is shown in Fig. 2c.

Where possible the sensor has been buried at least $60 \mathrm{~cm}$ below the surface on a $10-15 \mathrm{~cm}$ thick concrete pier. The sensor has been also shielded from the ground using buckets or tubes filled with fine river sand. An example of such installations is shown in Fig. 2d.

Another source of thermal instability when installing inside buildings is the floor itself that is in contact with the air of the room and with sun exposed walls. To minimize this a granite insulation base plate similar to that used in the Mediterranean Very Broadband Seismographic Network (MedNet, 1988) stations has been designed (one has been used with the STS2 - see Fig. 2b). Unfortunately due to new bureaucratic procedures the purchase of this base plates has been severely delayed and they were not yet available at the time of the installation. A few of this base plates will be installed at the next maintenance in the stations that appear to suffer most from floor instabilities.

To increase reliability and minimize on-site technical intervention, all the stations connected to the mains have been equipped with an industrial power supply and backup batteries (at least $80 \mathrm{Ah}$ ) accounting for the power consumption of the UMTS data transmission system. The two solar powered stations have been equipped with two independent solar power systems: one for the seismic station and one for the
UMTS router to minimize the probability of loosing seismic data. Moreover all stations have at least $8 \mathrm{~GB}$ of disk to store data with an autonomy of at least 8 months.

\subsection{Real-time data transmission and the experiment data management}

The benefits of portable real-time seismic networks are several and well known. During the management of a temporary experiment from the real-time data flow is possible to detect and quickly fix problems related to power supply, time synchronization, disk failures and, most important, seismic signal quality degradation due to unexpected noise sources or sensor alignment/tampering. This usually minimizes the field maintenance trips and maximizes both the quantity and the quality of the acquired data.

We routinely use a real-time UMTS based data acquisition system suitable for temporary experiments. The system developed at INGV is described in detail in Govoni et al. (2015). It consists of a VPN system that allows to connect all the stations to a data acquisition server using UMTS and/or any other internet connection.

Unfortunately at the beginning of the experiment only four UMTS devices were available and the purchase of new devices and SIM cards was severely delayed. Most of the stations have been connected only during spring 2016. Figure 8 shows the data availability of the real-time system. Despite the several small gaps typical of UMTS connections, the overall completeness of the real-time data is around $97 \%$, useful to monitor the data quality and to schedule the station maintenance.

At least 3-5 stations need to be optimized either installing a higher gain antenna or changing the service provider. This work will be done during the next scheduled maintenance.

The stations Z3.A312A and Z3.A313A, together with the 4 sites turned permanent, are also connected real-time with a similar UMTS based system used to acquire data of the regional accelerometric network (Lovati et al., 2014).

The data management of the experiment has been designed with the goal of having all data available on the INGV EIDA node as soon as possible. Figure 4 shows the block diagram of the data flow at the INGV data center.

The first path is formed by the real-time data flow. Data is collected via UMTS and made available to the National Seismic Server on an internal SeedLink server. From this point on the path is the same as for all the data collected by the National Network.

Data is fed to the monitoring system and used for the seismic monitoring and the bulletin. We do not automatically include the AASN data in the routine surveillance system due to the large number of triggers related to high anthropic noise at most of the stations. However, Z3 station data can be manually loaded during location revision if needed. We do use AASN data in the revised locations of the Bollettino Sismico Italiano (http://cnt.rm.ingv.it/bsi) published every four 

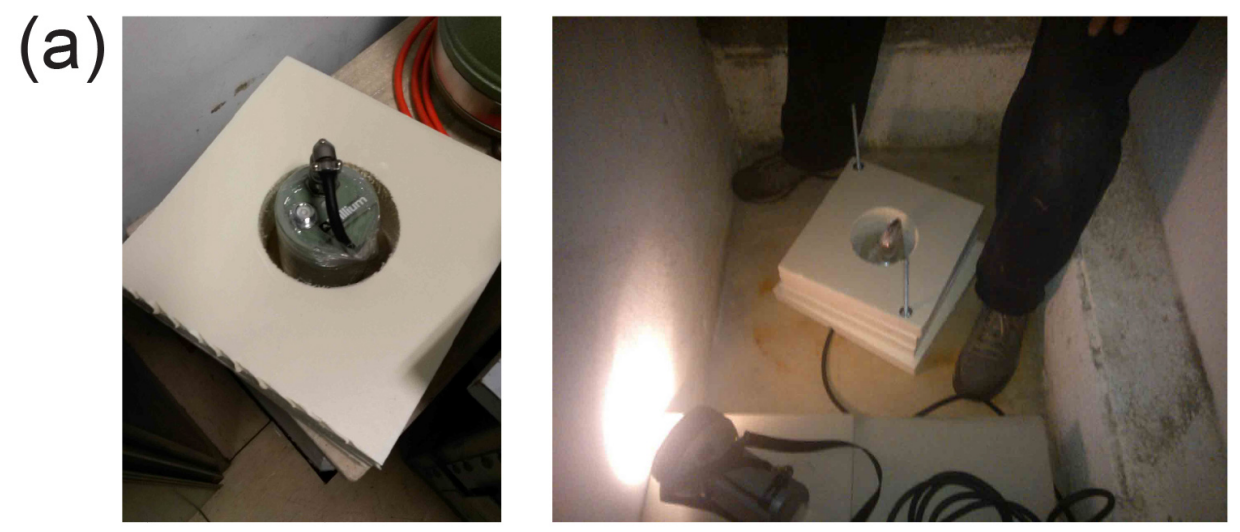
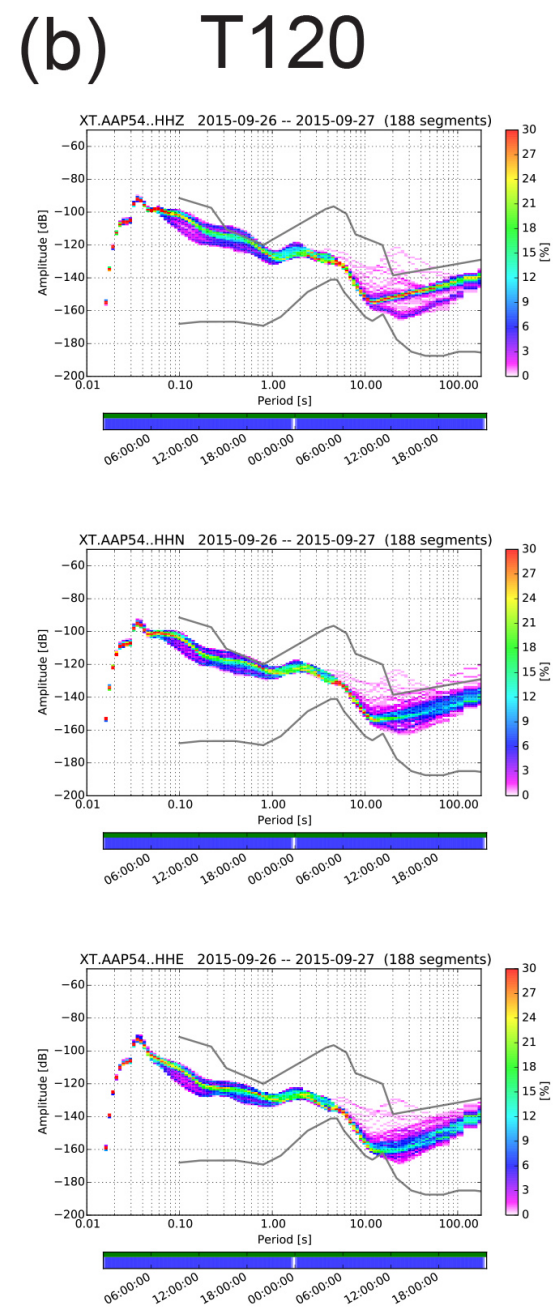

STS2
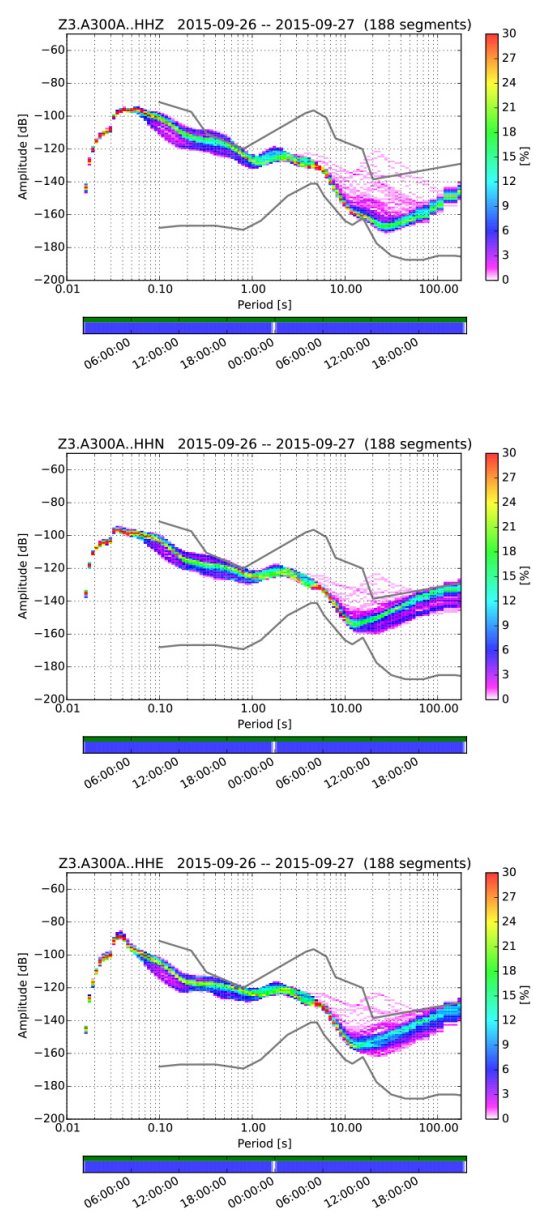

(c)

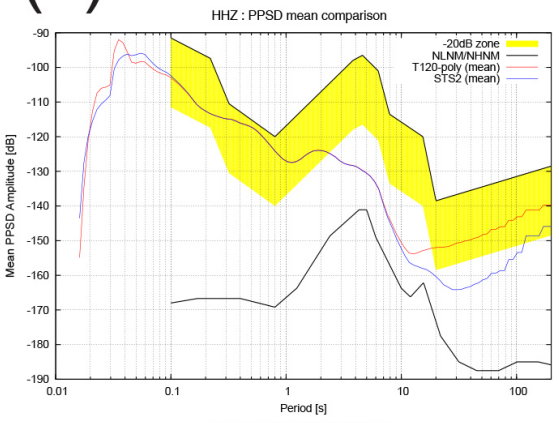

HHN : PPSD mean comparison

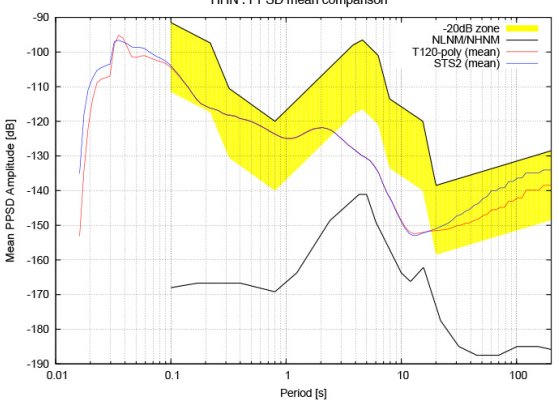

HHE: PPSD mean comparison

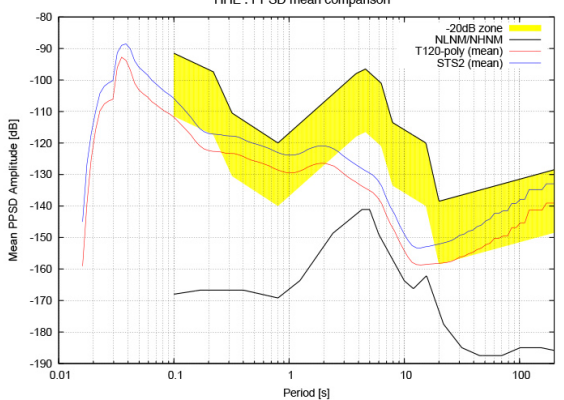

Figure 3. A custom made thermal insulation box for the Nanometrics Trillium Compact. The sensor is small and lightweight but these features are prone to signal pollution due to the strain of the cable and the high thermal capacity of the aluminium case. (a) the initial assembly of the $300 \times 300 \mathrm{~mm}$ polystyrene tiles with a central $128 \mathrm{~mm}$ hole. The sensor is wrapped using a packaging film so that the sensor cable is kept firmly to the body of the sensor and reaches the ground with a glazing angle. (b) PPSD plots computed on $48 \mathrm{~h}$ of continuous recording at 100 sps with the ObsPy library. On the left the Trillium 120c and on the right the Streckeisen STS2 (the station codes used are fictitious). (c) The means of the PPSD shown in (b) are compared for each component with the New Low/High Noise model, the yellow band is the $-20 \mathrm{~dB}$ from NHNM zone. With the insulation box the Trillium Compact has a noise comparable to the STS2 except for the vertical component that shows a bimodal behavior. 


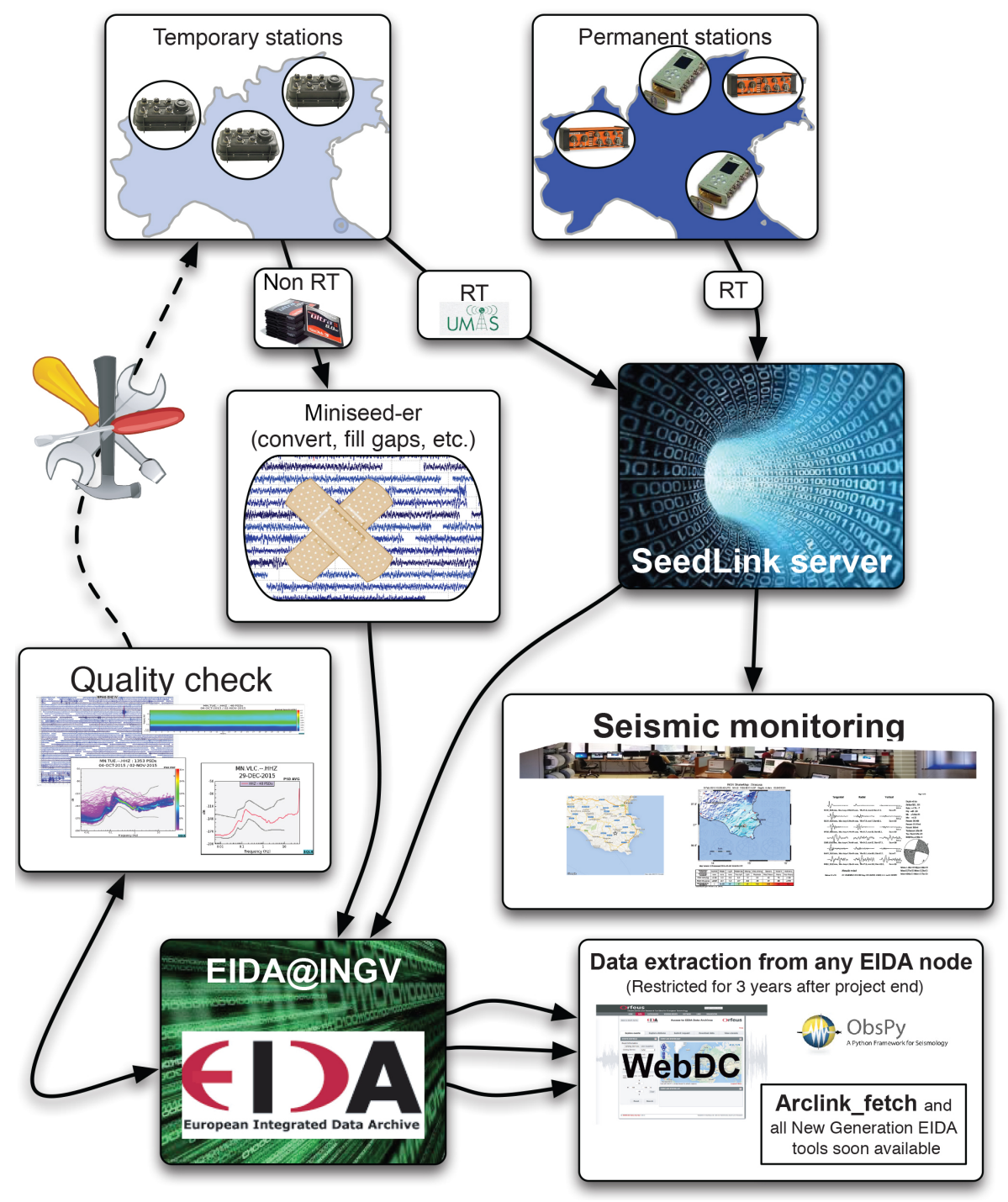

Figure 4. All temporary stations store continuous data in the native REF TEK binary format on Compact Flash support with at least $\sim 8$ months of autonomy. Every six months the stations are routinely serviced and the data is collected and processed to obtain a quality checked mini SEED archive that is exported to the INGV EIDA node. All but Z3.A316A (Montecristo) are equipped with UMTS routers and the data is also collected in real-time and made available to the INGV National Seismic Network for monitoring purposes and finally archived on the EIDA node. The State of Health ( $\mathrm{SOH}$ ) real-time data is used to diagnose technical problems to the station power supply, GPS timing system and seismic sensor.

months. The real-time data is directly archived to the INGV EIDA node and made available to authorized users.

Roughly every six months data is gathered from station disks during the periodic station maintenance, converted to mini SEED and exported to the EIDA node filling eventual transmission gaps.

The State of Health $(\mathrm{SOH})$ data is routinely analyzed from the real-time data flow to spot technical problems.

\section{Final stations configuration and site descriptions}

The scouting work began in August 2015 and by the end of the year all stations but Z3.A304A were installed, 4 of which real-time since the beginning. The Z3.A304A installation was delayed by bureaucratic problems with the permits, it was finally installed at the beginning of February, 2016. See Table 1 for station installation dates, sensor type, housing and equipment. The sensor housing type, as defined by SED and used for the AlpArray project, is for most stations (17) building, but there are also 2 free-field installations and 1 urban free-field site. Moreover, 2 sensors are deployed in 
buried hand-dug vaults. Only 2 stations are powered by solar panels, all the rest have power grid connection. In the following we give a short description for each of the temporary sites and their preliminary noise characterization.

Z3.A300A has been installed in the basement of a two storey modern building in the NE part of the Muzzana del Turgnano village (Udine, Friuli). The installation area is just a few tens of kilometers North of the Laguna di Marano and is composed of soft alluvial soil. The building, occasionally used by local Civil Protection, guarantees fair thermal insulation, power grid connection and the maximum level of security. The sensor has been thermally shielded with a $10 \mathrm{~cm}$ thick polystyrene box. However, the site is not very far from a state road (SS14), a warehouse and a water tower. Both high frequency and long period noise are quite close to the NHNM.

Z3.A301A is buried in the garden of a one-storey building in the Northern suburbs of the Isiata village (Venezia). The sensor is placed on a $10 \mathrm{~cm}$ thick concrete pier, about $60 \mathrm{~cm}$ below the surface, insulated with a bucket of sand. A plastic $60 \times 60 \mathrm{~cm}$ box protects the sensor from the soft ground around. The building, which ordinary hosts the packaging activities of an $\mathrm{ONG}$, guarantees power grid connection and a high level of security. The site is less than $50 \mathrm{~m}$ away from minor roads. The whole area was reclaimed at the beginning of the last century and is composed of very soft lacustrine soil. The water level at the time of the installation was at a depth of only $50 \mathrm{~cm}$, while the average altitude of the whole area is around $-8 \mathrm{~m}$ a.s.l. This is a typical case in which long period noise requirements are substantially met with a $-23 \mathrm{~dB}$ for vertical and $-7 \mathrm{~dB}$ for horizontal components (relative to NHNM), but the high frequency noise is substantially same order or slightly larger than the NHNM.

Z3.A302A is installed in a relatively recent one-storey industrial building hosting several rarely used municipality offices and warehouses, a few kilometers East of the Resana village (Treviso, Veneto). The site is connected to the power grid and offers a high level of security. The floor is made of a large thick concrete layer. Eventually the only office with enough space available for the installation was on the South side, therefore more prone to thermal variations of the walls and of the concrete floor (Fig. 2a). The sensor has been shielded with a custom dual wall plastic box with an additional $4 \mathrm{~cm}$ thick layer of polystyrene. While the PPSD levels are acceptable $(-13.6 \mathrm{~dB}$ for vertical and $-5 \mathrm{~dB}$ for horizontal components at long periods) the PPSD plot shows a highly bimodal behavior at both ends of the frequency spectrum, confirming daily thermal and cultural noise variations. The thermal insulation is going be optimized using a marble base plate like those used in the MedNet stations.

Z3.A303A is installed inside a Middle Age fortress located at Lido di Venezia (one of the islands of the coastal strip of the Venetian Lagoon). The fortress is inside the Golf Club area, which guarantees power grid connection and a high level of security (Fig. 2b). The sensor is placed at the furthest corner from the entrance, on a marble basement (to optimize thermal insulation) resting on a concrete floor and has been shielded with a custom dual wall plastic box with an additional $4 \mathrm{~cm}$ thick layer of polystyrene. The soil is mainly composed of consolidated sand. The noise level is overall satisfactory and meets the specifications at long periods, while at high frequencies is slightly above the requirements. At long periods the North component is roughly $5-7 \mathrm{~dB}$ above the Est components because of some site effect that will be investigated.

Z3.A304A is located inside a small bathroom $(2 \times 2 \mathrm{~m})$ of the local cemetery of Bellombra village (Rovigo, Veneto), with power grid connection and the highest level of security. The site is located in the deltaic and alluvial deposits of the Po River. The sensor is placed on a tile floor covering a $50 \mathrm{~cm}$ thick screed floor and is shielded by a plastic box sealed by foam. The site is $100 \mathrm{~m}$ from the nearest road, $300 \mathrm{~m}$ from a water well and $1 \mathrm{~km}$ from the village. Only the vertical component matches the noise level requirements at long periods. Horizontal components at both low and high frequency closely match the high noise model.

Z3.A305A is located in a small building inside the cemetery of $\mathrm{Ca}$ ' Zuliani village (Rovigo, Veneto), with power grid connection. The sensor is in the furthest corner from the door, placed directly on the concrete floor that is $1 \mathrm{~m}$ thick to reach the ground floor. The sensor has been covered with a plastic box with an additional $4 \mathrm{~cm}$ thick layer of polystyrene, sealed by foam. The site is $500 \mathrm{~m}$ far from the river and a secondary road. The site is located in the deltaic and alluvial deposits of the Po River. Being an alluvial plain site the noise level is satisfactory for the vertical component at long periods, while horizontal components approach the high noise level. Also high frequency noise is close or greater than the high noise level due to the high population density.

Z3.A306A is located inside a utility cabin, close to residential buildings in Località San Pietro (Viano, Reggio Emilia). The location guarantees power grid connection and the maximum level of security. The sensor is installed directly on the screed floor at the furthest corner from the main door and has been shielded by a plastic box with an additional $4 \mathrm{~cm}$ thick layer of polystyrene, sealed by foam. The site is on the top of a hill characterized by a succession of limestones and sandstones alternated with clay. The station overall matches the noise requirements, only the horizontal components enter the $-10 \mathrm{~dB}$ zone at periods higher than $80 \mathrm{~s}$.

Z3.A307A is located in a log cabin inside the protected natural area of "La Rizza" (Bentivoglio, Bologna). The site offers power grid connection and the maximum level of security. The sensor is placed on the concrete floor at ground level on the alluvial deposits of the Po River, and is shielded by a plastic box with an additional $4 \mathrm{~cm}$ thick layer of polystyrene, sealed by foam. Potential noise sources are the trees around the log cabin, while inside the cabin the presence of mice induced us to protect further the instrumentation with a fibre- 
glass box. The station barely matches the noise requirements with minor peaks at high frequencies.

Z3.A308A is located inside a building in the local cemetery of Longastrino village (Argenta, Ferrara). The location guarantees power grid connection and the highest level of security. The sensor is placed above a tile floor, in a corner of the room, close to the window but far from the door, and is covered with a plastic box with an additional $4 \mathrm{~cm}$ thick layer of polystyrene, sealed by foam. The cemetery is close to the main road $(50 \mathrm{~m})$ but $1 \mathrm{~km}$ far from the village. The site is located on the alluvial and deltaic deposits of the Po River. The noise requirements are met only on average. While the vertical components is satisfactory, both horizontal components suffer large daily variations due to the tile floor that we were not allowed to alter.

Z3.A309A is installed in an outdoor safe corner of the local cemetery of Martorano (Cesena), in the rear of the building in front of the main entrance. The location offers power grid connection and a high level of security. The sensor is placed on a concrete floor and it was protected from temperature variation with sand, foam panels and bricks. The site is located on the fluvio-continental and deltaic deposits of the Po plain and is $300 \mathrm{~m}$ from the main road. The noise requirements for soft soil are met with small high frequency exceptions.

Z3.A312A is installed in the basement of a municipal building (Bozzolo town, Mantova) lying on alluvial deposits (gravel and sand) of the Po plain. The sensor is placed above a tile floor and is shielded by a plastic box with an additional $4 \mathrm{~cm}$ thick layer of polystyrene. The site is at $30 \mathrm{~m}$ a.s.1. bordered on two sides by the yard of the building, by a street and a car park on the other two sides. The station has power grid connection and a buffer battery to compensate for a short time period the temporary power outage. The noise requirements for soft soil are met with small high frequency exceptions.

Z3.A313A is installed in a corner of the cemetery of Volta Mantovana (Mantova), lying on alluvial deposits (sand and clay) of the Po plain. The site is at $64 \mathrm{~m}$ a.s.l., limited by the cemetery wall on one side, by a street next to a canal on another side and by open fields on two sides. The sensor is placed on a concrete layer and is covered by a plastic box. The station has power grid connection and a buffer battery to compensate for a short time period the temporary power outage. The noise are met by the vertical components but both horizontal are already order of the high noise level for periods longer than $30 \mathrm{~s}$.

Z3.A316A is located inside the cellar of the Villa Reale building house in the Cala Maestra cove at the Monte Cristo Island (Fig. 2c). The geologic substratum consists of a monzogranite with large feldspars phenocrysts. The sensor is surrounded by thick $(80 \mathrm{~cm})$ walls and lies on a concrete base placed on the floor of the cellar, built directly on the granite. Only few persons live on the island. The station is powered by electric power line. The noise level is very satisfactory and suffers mainly of the sea waves influence.

Z3.A317A is located inside the cellar of the main building of the municipal hall at the Capraia Island. The geologic substratum consists of lava flows and pyroclastic deposits of an old volcano. Thick walls surround the sensor, which lies on a concrete base placed on the floor of the cellar, built directly on the lava flows. The station is powered by electric power line. The noise level is satisfactory with moderate high frequencies levels.

Z3.A318A is located between vineyards in the Argentiera estate (Donoratico, Livorno). The geologic substratum consists of sedimentary rocks (clay, marls and limestone). The sensor is completely buried and secured by fence and info labels (Fig. 2d). In the installation site the rock (marls and clay) crops out just one meter below the surface. In the estate few seasonal farm activities occur. The station is powered by solar panels. The noise levels are satisfactory.

Z3.A319A is located in a farm on the hills just north east of the small town of Santa Luce (Pisa). The geologic substratum consists of sedimentary rocks (clay, sand and limestone). The sensor is installed outdoor, locked to a substratum of concrete in order to maximize the coupling between soil and sensor. A double shelter has been used to maximize the thermal insulation of the sensor. Few seasonal farm activities occur in the area. The site is $2 \mathrm{~km}$ far from a wind power plant. The station is powered by solar panels. The noise levels are satisfactory but a bimodal behavior is evident.

IV.OPPE is installed in the back side of the cemetery of Oppeano (Verona) lying on alluvial deposits of the Po plain. The sensor is placed on a concrete plinth and is shielded by a $4 \mathrm{~cm}$ thick polystyrene inner casing, covered by a wooden outside box. The site is at $20 \mathrm{~m}$ a.s.l. limited by the wall of the cemetery on one side and by open fields on the three other sides. The station has power grid connection and a buffer battery to compensate for a short time period the temporary power outage. The noise level is satisfactory for all components at low frequencies, considered that it is an alluvial plain site. At high frequencies the noise is larger than the high noise level due to the high population density.

IV.ORZI is installed in the back side of the cemetery of Orzinuovi (Brescia) lying on alluvial deposits of the Po plain. The sensor lies on a concrete plinth and is covered by a $4 \mathrm{~cm}$ thick polystyrene box. The site is at $83 \mathrm{~m}$ a.s.l. bordered by the wall of the cemetery on one side and for the three other sides by open fields. The station has power grid connection and a buffer battery to compensate for a short time period the temporary power outage. The noise level is satisfactory for all components at low frequencies, considered that it is an alluvial plain site. At high frequencies the noise is larger than the high noise level due to the high population density.

IV.SARZ is installed in the basement of the school of Sarezzano (Alessandria) lying on sandstones and marls rocks, at the NW limit of the Northern Apennines. The sensor is placed directly on the ground and is shielded by a $4 \mathrm{~cm}$ 
thick polystyrene box. The site is at $266 \mathrm{~m}$ a.s.l. limited on two sides by the yard of the school and on the other two sides by a small square. The station has power grid connection and a buffer battery to compensate for a short time period the temporary power outage. Considered that this is a rocky site, the station performance is not fully satisfactory even if the noise level on average is below the high noise level.

IV.ZONE is installed in the basement of the school of Zone (Brescia) lying on lacustrine deposits of a valley whose slopes are characterized mainly by Val Sabbia sandstone and Esino limestone. The station is located at the Southern limit of the Central Alps, at $691 \mathrm{~m}$ a.s.1. surrounded on three sides by the school yard and bordered by a narrow street on the other side. The station has power grid connection and a buffer battery to compensate for a short time period the temporary power outage. The sensor is placed above a tile floor and is covered by a $4 \mathrm{~cm}$ thick polystyrene box. While the vertical component is satisfactory in the whole frequency range, horizontal components suffer from site effects at frequencies above $1 \mathrm{~Hz}$ and they are already order of the high noise level for periods longer than $30 \mathrm{~s}$.

\section{Seismic noise level and site effects}

All data acquired in the first 40-60 days from the station installation have been analyzed to asses the noise levels.

Figure 5 shows the mean of all stations PPSD grouped per type of site soil. We see immediately that all the rock sites meet the noise requirements with a minor exception in the high frequency band. The stations on soft soil (Po Plain and Adriatic coast) are instead very close to the maximum noise allowed for long periods (mainly order of $10 \mathrm{~dB}$ lower than the NHNM), but the high frequency noise is mainly order or higher than the NHNM, due to the high level of cultural noise in those areas.

Noise levels measured on horizontal components are on the average $15-20 \mathrm{~dB}$ higher than the vertical component in the long period range.

A more complete analysis will soon be possible using the first year of data to asses seasonal variations and eventually fix unsatisfactory stations during the next maintenance. A more detailed analysis of the noise performance of these stations will be the subject of a future study and is beyond the scope of this work.

The PPSD plots of all temporary stations can be accessed on http://coremo.rm.ingv.it/Projects/AlpArray/PPSD. This site has been developed specifically for hosting the AlpArray Italy project data and will be maintained and improved during the course of the project.

Nevertheless a first sensitivity analysis shows satisfactory results. The sensitivity is overall pretty good on all sites even if some site effect is evident on a few sites. Examples of local and telesismic event records are shown in Figs. 6 and 7. A more quantitative analysis of the sensitivity and of the detec-

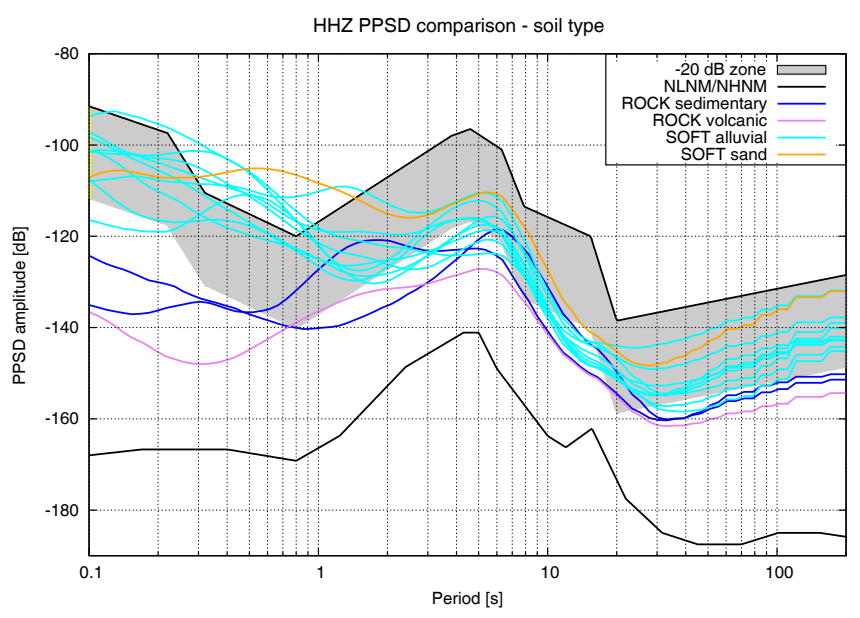

Figure 5. Comparison of the mean vertical PPSD of all the AASN stations managed by INGV as function of the soil type using the data of the first 40-60 days after installation. Gray lines represent the Peterson NHNM and NLNM, in gray the $-20 \mathrm{~dB}$ area below the NHNM. All rock sites are below or approach the NHNM $-20 \mathrm{~dB}$ level and satisfy reasonably well the experiment specification both at longer periods and at higher frequencies. Most soft soil site (mainly Po plain and Adriatic coast) are below the NHNM $-10 \mathrm{~dB}$ for long period but fail to meet the NHNM model for higher frequencies mostly because of cultural noise typical of those areas. The worst soft soil sites are only a few $\mathrm{dB}$ below the NHNM model at long periods. Basically the same behavior is observed for the horizontal components that at longer periods are usually at least $15 \mathrm{~dB}$ above the vertical component.

tion threshold of each station will soon be performed using the first year of data.

\section{Conclusions}

We deployed a total of 20 new broad-band stations in fall 2015 to complete the AASN in Italy in time for the official AlpArray project start of operations: 1 January 2016. Only one station (Z3.A304A) was delayed by municipality permits up to the beginning of February 2016.

While rock sites meet and sometimes exceed the project noise specifications, the sites on soft or alluvial soil are more challenging. Soft soil areas are also densely inhabited and present usually a difficult trade-off between quality of signal and security of housing. Never the less we were able to meet the project specifications in most sites for the long period (30-200 s) part. Not so good is the situation with high frequency noise $(1-20 \mathrm{~Hz})$ that is usually order of the NHNM in most soft soil sites. These most challenging sites are located in the Po plain and in the NorthEast Adriatic coast and very little can be done to improve the signal quality satisfying the geometric constrains. 

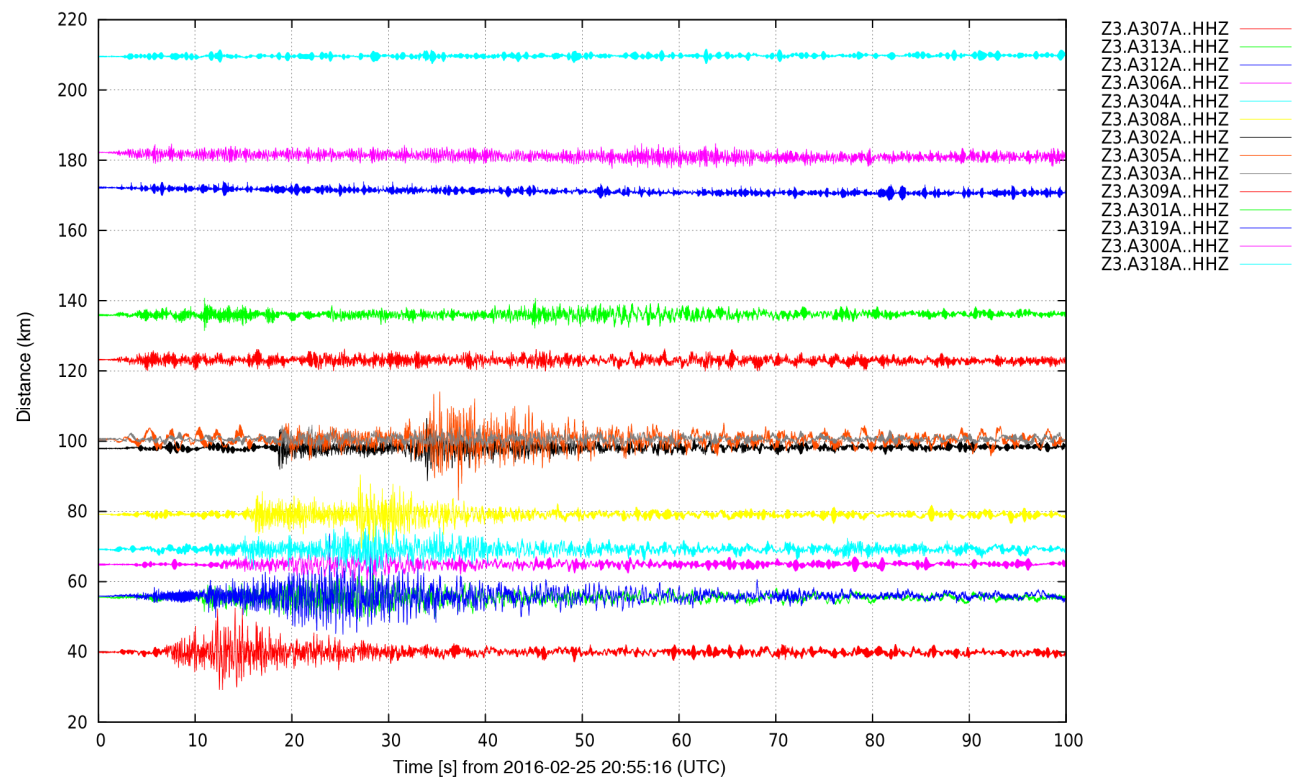

Figure 6. Example of waveforms recorded by the INGV AlpArray temporary stations for the M3.0 local earthquake occurred close to Poggio Rusco (Mantova, Italy) on 25 February 2016, 20:55:16 (UTC), $10 \mathrm{~km}$ focal depth. Waveforms are corrected for instrument response.
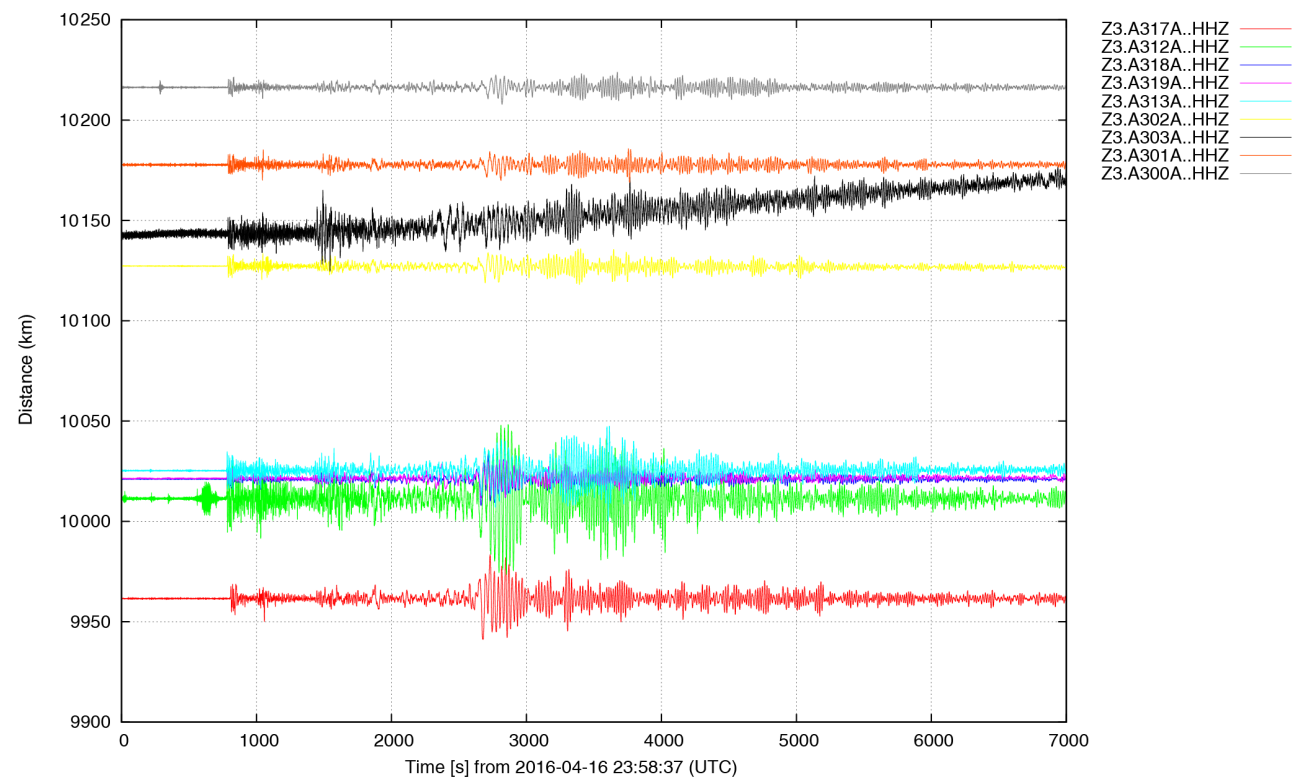

Figure 7. Example of waveforms recorded by the INGV AlpArray temporary stations for the M7.8 teleseismic earthquake occurred in Ecuador on 16 April 2016, 23:58:37 (UTC), focal depth 19.2 km. Waveforms are corrected for instrument response. The black trace is from Z3.A303A (Lido station) on shore in the coastal strip of venetian lagoon and the drift is very likely related to the water tides.

The first analysis of teleseismic and local events shows anyway that detection thresholds and sensitivity is acceptable even for very soft soil sites.

All stations but Z3.A316A (Montecristo) have been turned real-time using UMTS and are currently contributing to the Seismic National Network monitoring system and to the bulletin (Michelini et al., 2016). The real-time acquisition rates are order of $99 \%$ in best sites and a few sites experiencing transmission problems due to insufficient UMTS signal or service quality will be optimized soon after the summer.

Data availability. The AlpArray seismic stations are available on EIDA (http://www.orfeus-eu.org/eida/). The Z3 network is currently not publicly accessible by decision of the AlpArray Working Group. All Z3 waveform data and other restricted 


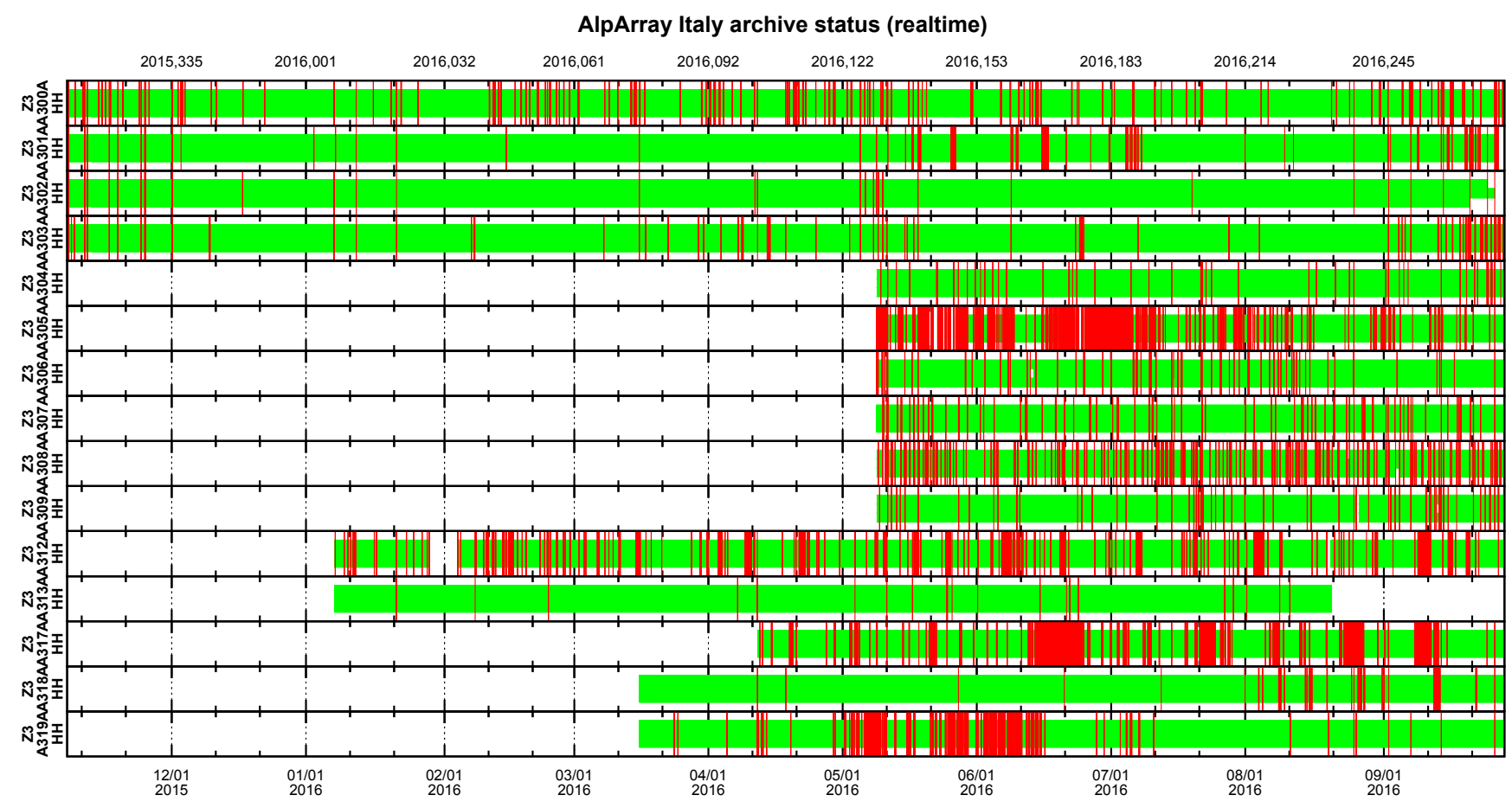

Figure 8. The real-time archive so far. Only 4 stations (Z3.A300A-Z3.A303A) were installed already equipped with UMTS routers. The equipment needed for real-time data transmission has been available for all stations only in spring 2016 and with all SIM cards from the same telephone company. At least 3-5 stations need to be optimized either installing a higher gain antenna or changing the service provider. This work will be done at the next scheduled maintenance around fall 2016 . The overall completeness of the data archive is around $97 \%$, very useful for monitoring the data quality and scheduling the station maintenance.

stations are exclusively available to registered members of the Core Group of the AlpArray Seismic Network. Visit http: //www.alparray.ethz.ch/seismic_network/backbone/data-access/ for further information on data access and http://www.alparray. ethz.ch/seismic_network/backbone/data-policy-and-citation/ for information of data policy. Information on the AlpArray project are available at www.alparray.ethz.ch.

In the AASN, the permanent stations are contributed via the following networks codes: BW, CH (Swiss Seismological Service , SED), CR, CZ (Institute of Geophysics, Academy of Sciences of the Czech Republic, 1973), FR (RESIF, 1995), G (Institut de Physique du Globe de Paris, IPGP), GE (GEOFON Data Centre, 1993), GR, GU (University of Genova, 1967), HS, HU (Kövesligethy Radó Seismological Observatory, 1992), IU (Albuquerque Seismological Laboratory, ASL), IV (INGV Seismological Data Centre, 1997), MN (MedNet project partner institutions, 1988), NI (OGS , Istituto Nazionale di Oceanografia e di Geofisica Sperimentale), OE, OX (OGS , Istituto Nazionale di Oceanografia e di Geofisica Sperimentale), PL, RD, RF (University of Trieste, 1993), SI, SK, SL, ST (Geological Survey-Provincia Autonoma di Trento, 1981), SX, TH.

Team list. The complete member list of the AlpArray Working Group can be found at http://www.alparray.ethz.ch.
Author contributions. A. Govoni and C. Piromallo prepared the manuscript with contributions from all co-authors. A. Govoni coordinated the station deployment together with C. Piromallo, S. Mazza and L. Margheriti. L. Bonatto developed procedures for data-set qualification and analysis. M. Moretti and M. Vallocchia managed the INGV mobile pool and the supplies. A. Govoni performed the instrument setup, the Huddle test, setup the real-time UMTS data acquisition system and developed most of the data management procedures. A. Govoni, L. Margheriti and A. Nardi participated to scouting, installation and maintenance of Z3.A300AZ3.A303A stations. F. Mazzarini, D. Piccinini and M. Capello participated to scouting, installation and maintenance of Z3.A316AZ3.A319 stations. S. Salimbeni, A. Cavaliere, S. Pondrelli and S. Danesi participated to scouting, installation and maintenance of Z3.A304A-Z3.A309 stations. Ezio D’Alema, S. Lovati, M. Santulin and M. Massa participated to scouting, installation and maintenance of Z3.A311A-Z3.A312A and IV.SARZ,IV.ORZI, IV.OPPE, IV.ZONE stations. The AlpArray Working Group worked out the network layout, the quality guidelines and the standards for the seismic data exchange.

Competing interests. The authors declare that they have no conflict of interest. 
Acknowledgements. We do thank all people, municipality staff and the State Forestry Corps (Corpo Forestale dello Stato) for hosting the seismic stations and for their help during the site scouting, installation and maintenance.

We do acknowledge the incredible organization and planning work done by the AlpArray project coordinators Edi Kissling, György Hetenyi, Irene Molinari and John Clinton at ETH, Zurich.

We also wish to thank Paolo Casale and Augusto Bucci, MEDNET staff, for valuable suggestions and discussions on very broad band site selection and installation, and Alfonso Mandiello for his help in data management.

We are grateful to the INGV Earthquake Division for the main financial support allocated to the project (INGV internal funds). We acknowledge as well Daniela Pantosti, Alberto Michelini, Paolo Augliera, Gilberto Saccorotti and Francesca Quareni (Departments Directors) for encouragement.

We thank the INGV National Seismic Network staff for help and support for the data management procedures.

We are grateful to Florian Fuchs and Irene Molinari for the useful suggestions that greatly improved the paper.

All plots and maps were prepared using the GMT (Wessel and Smith, 1998) and gnuplot (Williams and Kelley, 2016) packages. Most data processing (notably PPSD and waveform deconvolution) was done using the ObsPy (Beyreuther et al., 2010) package.

Edited by: D. Pesaresi

Reviewed by: F. Fuchs and one anonymous referee

\section{References}

Albuquerque Seismological Laboratory (ASL)/USGS: Global Seismograph Network (GSN - IRIS/USGS). International Federation of Digital Seismograph Networks, Other/Seismic Network, doi:10.7914/SN/IU, 1988.

AlpArray Seismic Network: AlpArray Seismic Network (AASN) temporary component, AlpArray Working Group, Other/Seismic Network, doi:10.12686/alparray/z3_2015, 2015.

Beyreuther, M., Barsch, R., Krischer, L., Megies, T., Behr, Y., and Wassermann, J.: ObsPy: A Python Toolbox for Seismology, Seismological Research Letters, 81, 530-533, doi:10.1785/gssrl.81.3.530, 2010.

GEOFON Data Centre: GEOFON Seismic Network, doi:10.14470/TR560404, 1993.

Geological Survey-Provincia Autonoma di Trento: Trentino Seismic Network, International Federation of Digital Seismograph Networks, Other/Seismic Network, doi:10.7914/SN/ST, 1981.

Govoni, A., Margheriti, L., Moretti, M., Lauciani, V., Sensale, G., Bucci, A., and Criscuoli, F.: UMTS rapid response real-time seismic networks: implementation and strategies at INGV, Adv. Geosci., 41, 35-42, doi:10.5194/adgeo-41-35-2015, 2015.

INGV Seismological Data Centre: Rete Sismica Nazionale (RSN), Istituto Nazionale di Geofisica e Vulcanologia (INGV), Italy, doi:10.13127/SD/X0FXnH7QfY, 1997.

Institut de Physique du Globe de Paris (IPGP) and Ecole et Observatoire des Sciences de la Terre de Strasbourg (EOST): GEOSCOPE, French Global Network of broad band seismic stations, Institut de Physique du Globe de Paris (IPGP), doi:10.18715/GEOSCOPE.G, 1982.
Institute of Geophysics, Academy of Sciences of the Czech Republic: Czech Regional Seismic Network, International Federation of Digital Seismograph Networks, Other/Seismic Network, doi:10.7914/SN/CZ, 1973.

Kövesligethy Radó Seismological Observatory: (Geodetic and Geophysical Institute, Research Centre for Astronomy and Earth Sciences, Hungarian Academy of Sciences (MTA CSFK GGI KRSZO)), Hungarian National Seismological Network, doi:10.14470/UH028726, 1992.

Krischer, L., Megies, T., Barsch, R., Beyreuther, M., Lecocq, T., Caudron, C., and Wassermann, J.: ObsPy: a bridge for seismology into the scientific Python ecosystem, Computational Science \& Discovery, 8, 014003, http://stacks.iop.org/1749-4699/8/i=1/ $\mathrm{a}=014003,2015$.

Lovati, S., Picarreda, D., and Massa, M.: NETHIX WE-120: un dispositivo di telecontrollo per l'ottimizzazione di sistemi di trasmissione di dati sismologici in tempo reale, Rapporti Tecnici INGV (ISSN 2039-7941), 278, 1-22, http://istituto.ingv. it/l-ingv/produzione-scientifica/rapporti-tecnici-ingv/archivio/ rapporti-tecnici2014/2014-05-28.4171101920, 2014.

Marzorati, S. and Bindi, D.: Ambient noise levels in north central Italy, Geochem. Geophy. Geosy., 7, q09010, doi:10.1029/2006GC001256, 2006.

MedNet project partner institutions: Mediterranean Very Broadband Seismographic Network (MedNet), Istituto Nazionale di Geofisica e Vulcanologia (INGV), doi:10.13127/SD/fBBBtDtd6q, 1988.

Michelini, A., Margheriti, L., Cattaneo, M., Cecere, G., D’Anna, G., Delladio, A., Moretti, M., Pintore, S., Amato, A., Basili, A., Bono, A., Casale, P., Danecek, P., Demartin, M., Faenza, L., Lauciani, V., Mandiello, A. G., Marchetti, A., Marcocci, C., Mazza, S., Mele, F. M., Nardi, A., Nostro, C., Pignone, M., Quintiliani, M., Rao, S., Scognamiglio, L., and Selvaggi, G.: The Italian National Seismic Network and the earthquake and tsunami monitoring and surveillance systems, Adv. Geosci., 43, 31-38, doi:10.5194/adgeo-43-31-2016, 2016.

Molinari, I., Clinton, J., Kissling, E., Hetényi, G., Giardini, D., Stipcevic, J., Dasovic, I., Herak, M., Šipka, V., Wéber, Z., Gráczer, Z., Solarino, S., the Swiss-AlpArray Field Team, and the AlpArray Working Group: Swiss-AlpArray temporary broadband seismic stations deployment and noise characterization, Adv. Geosci., 43, 15-29, doi:10.5194/adgeo-43-15-2016, 2016.

Moretti, M., Margheriti, L., and Govoni, A.: Rapid Response to the Earthquake Emergencies in Italy: Temporary Seismic Networks Coordinated Deployments in the Last Five Years, 585599, Springer International Publishing, Cham, doi:10.1007/9783-319-21753-6_24, 2016.

OGS (Istituto Nazionale di Oceanografia e di Geofisica Sperimentale) and University of Trieste: North-East Italy Broadband Network, International Federation of Digital Seismograph Networks, Other/Seismic Network, doi:10.7914/SN/NI, 2002.

OGS (Istituto Nazionale di Oceanografia e di Geofisica Sperimentale): North-East Italy Seismic Network, International Federation of Digital Seismograph Networks, Other/Seismic Network, doi:10.7914/SN/OX, 2016.

Peterson, J.: Observations and modeling of seismic background noise, Tech. rep., USGS Open-File Report, 1993.

RESIF: RESIF-RLBP French Broad-band network, RESIF-RAP strong motion network and other seismic stations in metropolitan 
France, RESIF - Réseau sismologique \& géodésique français, doi:10.15778/RESIF.FR, 1995.

Swiss Seismological Service (SED) at ETH Zürich: National Seismic Networks of Switzerland, ETH Zürich, doi:10.12686/sed/networks/ch, 1983.

University of Genova: Regional Seismic Network of North Western Italy, International Federation of Digital Seismograph Networks, Other/Seismic Network, doi:10.7914/SN/GU, 1967.

University of Trieste: Friuli Venezia Giulia Accelerometric Network, International Federation of Digital Seismograph Networks, Other/Seismic Network, doi:10.7914/SN/RF, 1993.
Wessel, P. and Smith, W. H. F.: New, improved version of generic mapping tools released, Eos, Transactions American Geophysical Union, 79, 579-579, doi:10.1029/98EO00426, 1998.

Williams, T. and Kelley, C.: gnuplot User Manual, http://www. gnuplot.info/documentation.html (last access: 1 March 2017), 2016. 